\title{
Immune response (IgG) following full inoculation with BNT162b2 COVID-19 mRNA among healthcare professionals
}

\author{
ARISTIDIS TSATSAKIS $^{1^{*}}$, ELENA VAKONAKI ${ }^{1 *}$, MANOLIS TZATZARAKIS $^{1^{*}}$, MATTHAIOS FLAMOURAKIS $^{2 * *}$ \\ TAXIARCHIS KONSTANTINOS NIKOLOUZAKIS ${ }^{1 * *}$, KONSTANTINOS POULAS $^{3}$, GEORGIOS PAPAZOGLOU $^{4}$, \\ ELEFTHERIA HATZIDAKI ${ }^{5}$, NIKOLAS C. PAPANIKOLAOU ${ }^{6}$, NIKOLAOS DRAKOULIS ${ }^{7}$, \\ EVANGELIA ILIAKI ${ }^{6}$, GEORGIOS N. GOULIELMOS ${ }^{8}$, MANOLIS KALLIONAKIS ${ }^{1}$, \\ GEORGIOS LAZOPOULOS $^{9}$, STELIOS KTENIADAKIS ${ }^{10}$, ATHANASIOS ALEGKAKIS ${ }^{1}$, \\ KONSTANTINOS FARSALINOS ${ }^{3,11}$ and DEMETRIOS A. SPANDIDOS ${ }^{12}$
}

\begin{abstract}
${ }^{1}$ Laboratory of Toxicology, Medical School, University of Crete, 71003 Heraklion; ${ }^{2}$ Department of General Surgery, Venizeleion General Hospital, 71409 Heraklion; ${ }^{3}$ Laboratory of Molecular Biology and Immunology, Department of Pharmacy, University of Patras, 26500 Rio-Patras; ${ }^{4}$ Department of Emergency Medicine, Venizeleion General Hospital, 71409 Heraklion; ${ }^{5}$ Department of Neonatology and Neonatal Intensive Care Unit, University Hospital of Heraklion, 71500 Heraklion; ${ }^{6}$ Department of Internal Medicine, Venizeleion General Hospital, 71409 Heraklion; ${ }^{7}$ Research Group of

Clinical Pharmacology and Pharmacogenomics, Faculty of Pharmacy, School of Health Sciences, National and Kapodistrian University of Athens, 15772 Athens; ${ }^{8}$ Section of Molecular Pathology and Human Genetics, Department of Internal Medicine, School of Medicine, University of Crete, 71003 Heraklion; ${ }^{9}$ Department of Cardiothoracic Surgery,

University Hospital of Heraklion, 71500 Heraklion; ${ }^{10}$ Emergency Department, Venizeleion General Hospital,

71409 Heraklion; ${ }^{11}$ Department of Public and Community Health, University of West Attica, 11521 Athens;

${ }^{12}$ Laboratory of Clinical Virology, Medical School, University of Crete, 71003 Heraklion, Greece
\end{abstract}

Received July 31, 2021; Accepted September 6, 2021

DOI: $10.3892 / \mathrm{ijmm} .2021 .5033$

\begin{abstract}
Soon after the beginning of the severe acute respiratory syndrome coronavirus 2 (SARS-CoV-2) pandemic in December, 2019, numerous research teams, assisted by vast capital investments, achieved vaccine development in a fraction of time. However, almost 8 months following the initiation of the European vaccination programme, the need for prospective monitoring of the vaccine-induced immune response, its determinants and related side-effects remains
\end{abstract}

Correspondence to: Professor Aristidis Tsatsakis or Dr Elena Vakonaki, Laboratory of Toxicology, Medical School, University of Crete, Voutes, 71003 Heraklion, Greece

E-mail: tsatsaka@uoc.gr

E-mail: evakonaki@med.uoc.gr

${ }^{* * * *}$ Contributed equally

Abbreviations: SARS-CoV-2, severe acute respiratory syndrome coronavirus 2; COVID-19, coronavirus disease 2019; IgG, immunoglobulin G; ACE2, angiotensin-converting enzyme 2; RBD, receptor binding domain; ICU, intensive care unit; WHO, World Health Organization

Key words: antibody titers, SARS-CoV-2, COVID-19, vaccination, BNT162b2 COVID-19 mRNA, IgG a priority. The present study aimed to quantify the immune response following full vaccination with the BNT162b2 coronavirus disease 2019 (COVID-19) mRNA vaccine by measuring the levels of immunoglobulin $\mathrm{G}(\mathrm{IgG})$ titers in healthcare professionals. Moreover, common side-effects and factors associated with IgG titers were identified. For this purpose, blood samples from 517 individuals were obtained and analysed. Blood sampling was performed at a mean period of $69.0 \pm 23.5$ days following the second dose of the vaccine. SARS-CoV-2 IgG titers had an overall mean value of $4.23 \pm 2.76$. Females had higher titers than males (4.44 \pm 2.70 and $3.89 \pm 2.84$, respectively; $P=0.007)$, while non-smokers had higher titers than smokers (4.48 \pm 2.79 and $3.80 \pm 2.64$, respectively; $\mathrm{P}=0.003)$. An older age was also associated with lower antibody titers $(\mathrm{P}<0.001)$. Moreover, the six most prevalent adverse effects were pain at the injection site $(72.1 \%)$, generalized fatigue $(40.5 \%)$, malaise $(36.3 \%)$, myalgia $(31,0 \%)$, headache $(25.8 \%)$ and dizziness/weakness $(21.6 \%)$. The present study demonstrated that the immune response after receiving the BNT162b2 COVID-19 mRNA vaccine is dependent on various modifiable and non-modifiable factors. Overall, the findings of the present study highlight two key aspects of the vaccination programs: First, the need for prospective immunosurveillance studies in order to estimate the duration of immunity, and second, the need to identify those individuals who are at a greater risk of developing low IgG titers in order to evaluate the need for a third dose of the vaccine. 


\section{Introduction}

Human coronaviruses have long been known to the scientific community since their first discovery in the 1960s; however, severe acute respiratory syndrome coronavirus 2 (SARS-CoV-2) is a new member of the Coronaviridae family (1). These viruses have a zoonotic source, with bats being the presumed reservoirs $(2,3)$. The disease caused by SARS-CoV-2 is known as the corona virus disease-19 (COVID-19) and was officially described in December, 2019 in Wuhan, China. Following intensive research on SARS-CoV-2 biology, it is now known that it expresses four structural proteins: Spike (S), nucleocapsid (N), envelope (E) and membrane (M) proteins (4). It has been proven that among these four proteins, the $\mathrm{S}$ protein plays the most crucial role in SARS-CoV-2 infection, since it mediates viral attachment, fusion and entry into host cells. The S protein consists of two domains, S1 and S2, from which the $\mathrm{S} 1$ domain has been proven to mediate the initial binding to the angiotensin-converting enzyme 2 (ACE2) receptor via its receptor binding domain (RBD) (5), while the C-terminal subunit (S2 domain) entails the fusion of virus with the cellular membranes (6). It has been demonstrated that polyclonal antibodies that specifically targeted SARS-CoV-2 $\mathrm{S}$ protein were able to inhibit SARS-CoV-2 entry into target human cells that expressed ACE2 (7). ACE2 is expressed on the cellular membrane of a variety of organs, including the lungs, kidneys, heart, arteries and cerebral cortex. Even though the primary manifestations of COVID-19 arise from the respiratory system (namely pneumonia and acute respiratory distress syndrome) (8), it is well known that COVID-19 also affects other systems, the majority of which express ACE2. Such extra-respiratory manifestations may include neurological, gastrointestinal and cardiovascular dysfunctions (9-12). Even though the majority of infected individuals will develop mild-to-moderate disease, a fraction of patients will be hospitalized in order to receive oxygen supplementation and supportive therapy $(13,14)$. In addition, some of these patients will require intensive care unit (ICU) admission and mechanical ventilation due to cardiorespiratory decompensation. In fact, it has been well established that such cases are associated with a higher mortality rate (15).

As part of the global effort to halt the progression of SARS-CoV2 and its negative impact on health, various vaccines have been developed, and under certain legislation, have been distributed for mass use. In Greece, the BNT162b2 COVID-19 mRNA vaccine was the first vaccine available and healthcare professionals were prioritized for vaccination. Since the vaccine was developed and authorized under a conditional market authorization regime, safety and efficacy parameters, such as the duration of immunity, need to be closely monitored and examined (16). The aim of the present study was to examine the immune response to the BNT162b2 COVID-19 mRNA vaccine among healthcare professionals and to identify determinants of antibody titers.

In order to measure antibody titers [immunoglobulin (Ig)A, $\operatorname{IgM}$ and $\mathrm{IgG}]$, serological tests on whole blood, serum, plasma or saliva are usually performed. Some of these are qualitative, while others are semi-quantitative and others quantitative $(11,17,18)$. The present study utilized semi-quantitative ELISA in order to evaluate IgG titers in the serum of vaccinated individuals who have received two doses of the BNT162b2 COVID-19 mRNA vaccine.

\section{Subjects and methods}

Population characteristics and sample collection. Healthcare professionals working at the Venizeleion General Hospital of Heraklion and the General Hospital of Ierapetra, (both located in Crete, Greece) were invited to participate in the present study through public announcements in each hospital. Sample collection was performed from March to June, 2021. The study was approved by the Ethics Committees and Scientific Councils of University Hospital of Heraklion (PAGNI), Venizeleion General Hospital of Heraklion, General Hospital of Ierapetra, and written informed consent was obtained from all participants. All samples generated by the present study were anonymized, and personal data were managed according to the EU General Data Protection Regulation (GDPR; https://gdpr-info.eu/). Demographics and anthropometric characteristics were recorded using a questionnaire. The collected information included age, sex, weight, height and smoking habits. Additionally, the nutritional status of the participants was recorded based on a self-report of any known deficiencies in vitamins (vitamin D, vitamin B12 and folic acid) and iron $(\mathrm{Fe})$, since such deficiencies may be linked to an inadequate immune response $(19,20)$. Furthermore, the use of immunomodulatory substances (such as corticosteroids) and a medical history of any chronic disease were also recorded. Participants were asked to keep a diary of any adverse effects, using a predetermined list of 27 adverse effects that were stratified into five categories (localized symptoms, allergic reactions, neurological/sensory symptoms, cardio-pulmonary and systemic symptoms). The exclusion criteria were the following: i) Individuals who had not received any dose of the BNT162b2 COVID-19 mRNA vaccine; ii) individuals who have received only the first dose of the vaccine; and iii) the unwillingness of the individual to participate in the study. In total, 517 individuals were included, of which 319 reported the exact dates of their vaccinations. According to the medical history of the participants, no one had been affected by SARS-CoV-2 at the time of blood sampling.

Blood sampling was performed by obtaining $3 \mathrm{ml}$ of venous blood. The sample was placed in vials and centrifuged for $10 \mathrm{~min}$ at 2,900 $\mathrm{x} \mathrm{g}$ at room temperature in order to separate serum. All samples were kept at $-20^{\circ} \mathrm{C}$ until further analysis.

Sample analysis. The analysis of the samples was performed using ELISA with a semi-quantitative ELISA test kit (BIO-SHIELD, 2019-nCoV IgG; cat. no. C1148/C1196; Prognosis Biotech SA) for the determination of IgG antibodies against SARS-CoV-2 in the serum of individuals who had been fully vaccinated (two doses) with the BNT162b2 COVID-19 mRNA vaccine, as per the manufacturer's instructions. The wells of the microtiter strips were coated with a mixture of different recombinant epitopes of SARS-CoV-2 $\mathrm{S}$ protein, including the SARS-CoV-2 S protein. The diluted serum specimens, positive controls, cut-off controls and negative controls provided with the ELISA assay were added to the wells of the microtiter plate. The antibody isotypes against SARS-CoV-2 in the specimens or controls (if present) bind 
Table I. Demographic and somatometric measures of the 517 participants.

\begin{tabular}{|c|c|}
\hline Characteristic & Measurement values \\
\hline \multicolumn{2}{|l|}{ Sex, n $(\%)$} \\
\hline Female & $343(66.3)$ \\
\hline Male & $174(33.7)$ \\
\hline Smoking status (yes), n (\%) & $178(34.4)$ \\
\hline \multicolumn{2}{|l|}{ Age groups, divided in years, $\mathrm{n}(\%)$} \\
\hline$\leq 30$ & $56(11.0)$ \\
\hline $31-40$ & $75(14.8)$ \\
\hline $41-50$ & $130(25.6)$ \\
\hline $51-60$ & $198(39.0)$ \\
\hline$\geq 61$ & $49(9.6)$ \\
\hline Age, years; mean \pm SD (range) & $47.7 \pm 11.6(23-87)$ \\
\hline \multicolumn{2}{|l|}{ BMI groups $\left(\mathrm{kg} / \mathrm{m}^{2}\right), \mathrm{n}(\%)$} \\
\hline$<20$ & $24(4.9)$ \\
\hline$\geq 20$ and $<25$ & $176(36.6)$ \\
\hline$\geq 25$ and $<28$ & $111(23.1)$ \\
\hline$\geq 28$ and $<30$ & $58(12.1)$ \\
\hline$\geq 30$ & $112(23.2)$ \\
\hline $\mathrm{BMI}\left(\mathrm{kg} / \mathrm{m}^{2}\right) ;$ mean $\pm \mathrm{SD}($ range $)$ & $26.7 \pm 5.0(17.4-59.3)$ \\
\hline Weight (kg) & $75.4 \pm 16.9(45.5-190)$ \\
\hline Height (m) & $1.68 \pm 0.09(1.49-2.00)$ \\
\hline
\end{tabular}

Age was registered for 508 cases and BMI for 481 cases. BMI, body mass index.

to the coated recombinant $\mathrm{S}$ protein epitopes. Any unbound immunoglobulin was removed with a washing step. A detection solution with the same mixture of recombinant epitopes of SARS-CoV-2 S protein, conjugated to HRP, provided with the ELISA assay was added and a double antigen sandwich system was formed. The detection reagent that did not react was removed by washing. A chromogen substrate was added to the wells resulting in the progressive development of a blue coloured complex with the detection reagent.

Colour development was then terminated by the addition of stop solution. The measurement was performed photometrically at $450 \mathrm{~nm}$ and the intensity of the produced coloured complex was proportional to antibodies present in the specimen. The presence of $\mathrm{IgG}$ against SARS-CoV-2 S protein in an individual specimen was determined by comparing the optical density of the specimen to the optical density of the cut-off control.

According to the instructions provided with the assay, the recorded intra-assay precision (\% CV values) for one negative and three positive samples that were assayed 42 times were $6.7 \%$ for the negative specimen and from 3.7 to $4.2 \%$ for the positive specimen, and the recorded inter-assay precision (\% CV values) for one negative and 3 positive samples assayed in 10 separate runs over 14 days were $7.1 \%$ for the negative and from 3.1 to $4.4 \%$ for the positive samples (according the assay brochure, version 2020-04-03/rev. 03, BIO-SHIELD
2019-nCoV IgG). The results from the specimens are expressed by the ratio of specimen OD/cut-off control mean OD. A specimen ratio $<0.8$ was considered as negative, a ratio between 0.8 and 1.0 was considered to be 'equivocal' and ratios $r \geq 1$ were considered as positive.

Statistical analysis. In order to evaluate the induced immune response from the two doses of the vaccine, antibody titers were evaluated in 517 individuals. Categorical variables were expressed as number (n) and percentage (\%), while continuous variables as the mean $\pm \mathrm{SD}$ and median. Due to the non-normal distribution of SARS-2-COVID19 antibodies, a Mann-Whitney test was applied for comparing antibody levels between two groups and a Kruskal-Wallis test was applied for comparisons between more than two groups. The correlation between two variables was examined using Spearman's Rho. Multivariate linear regression analysis was applied to establish correlates of SARS-CoV-2 antibody titers, with demographics, time of sampling relative to vaccination and adverse/side effects being used as independent variables in the model. Bar charts and scatterplots were applied for data presentation. IBM SPSS Statistics 26.0 was used for data analysis (IBM Corp.). $\mathrm{P}<0.05$ was considered to indicate a statistically significant difference.

\section{Results}

Due to the self-reported completion of the questionnaire, certain data on demographics, such as age (508 valid cases, 98.2\%) and body mass index (BMI; 481 valid cases, 93.0\%) were not provided. Moreover, there was a marked number of missing values in the date of vaccination or in the questionnaire completion, with 319 participants providing complete data for vaccination dates.

The demographics and anthropometric characteristics of the study participants are presented in Table I. The mean age was 47.7 years, ranging from 23 to 87 years, while the majority of the participants were 51-60 years of age. Approximately two-thirds of the participants were females. The distribution of BMI revealed that $4.9 \%$ of the individuals were underweight $\left(<20 \mathrm{~kg} / \mathrm{m}^{2}\right), 36.6 \%$ were of normal weight (BMI $\geq 20$ and $<25 \mathrm{~kg} / \mathrm{m}^{2}$ ), $32.4 \%$ were overweight $(23 \%$, ranging from 25 up to $28 \mathrm{~kg} / \mathrm{m}^{2}$ and $12 \%$ ranging from 28 to $30 \mathrm{~kg} / \mathrm{m}^{2}$ ), while $23.2 \%$ were obese $\left(\geq 30 \mathrm{~kg} / \mathrm{m}^{2}\right)$. For the remaining $6.9 \%$ of the participants, no data for BMI were provided by the participants. Smokers comprised $34.4 \%$ of the participants.

The data on the self-reported nutritional status and the use of immunomodifiers are presented in Table SI. Vitamin D deficiency was the most prevalent deficiency reported, followed by Fe deficiency. The use of immunomodifiers was reported by $9.1 \%$ of the participants, from which $4.8 \%$ reported the use of corticosteroids. As regards the presence of chronic diseases among the participants, this was reported in only $0.9 \%$ (Table SI).

The six most prevalent adverse effects were pain at the injection site (72.1\%), generalized fatigue/discomfort (40.5\%), malaise/sickness (36.3\%), myalgia (31.0\%), headache $(25.8 \%)$ and dizziness/weakness (21.6\%) (Fig. 1). Of note, less than one fifth of the participants did not report any adverse effects. The prevalence of adverse effects among participants, both 


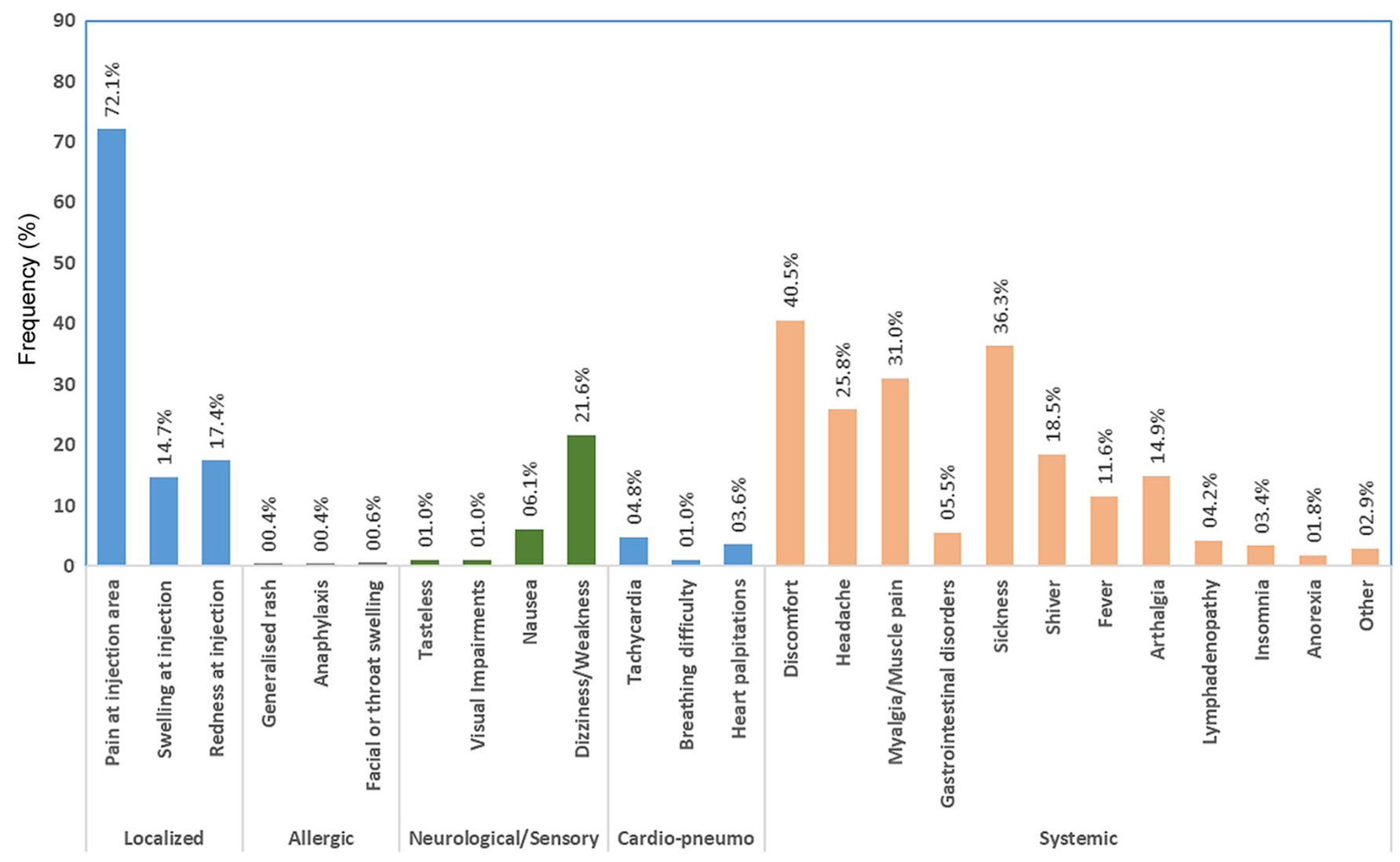

Figure 1. Categorization of symptoms and prevalence of each symptom for the 517 participants in the present study.

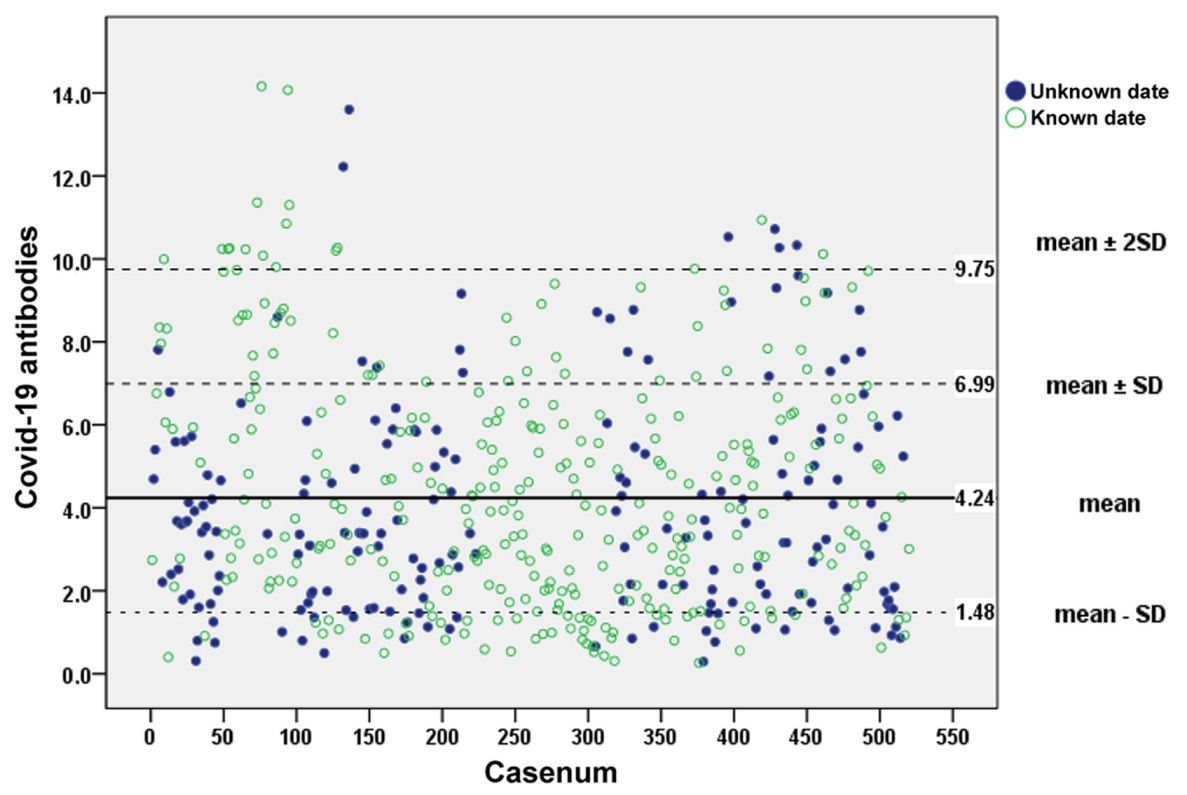

Figure 2. The mean levels and their normal limits (mean \pm SD, mean $\pm 2 \mathrm{SD}$ ) of the anti-SARS-CoV-2 IgG antibodies. Blue dots refer to antibodies with an unknown date of vaccination and green dots to the known dates of vaccination.

separately for each effect and for each category of effects is presented in Table SII.

The SARS-CoV-2 antibody titers ranged from 0.26 to 14.16 , with a mean value of $4.23 \pm 2.76$. The scatterplot illustrated in Fig. 2 presents the measurements of the whole study group (517 participants) performed using ELISA. The mean \pm 2 SD value indicates the limits of estimated SARS-CoV-2 antibodies at 9.75 . Out of the 517 individuals that were included, 198 (38.3\%) did not report one or both dates of their vaccination with the BNT162b2 COVID-19 mRNA vaccine. However, a comparison of the mean value of the $\operatorname{IgG}$ titer of the group with known vaccination dates (319 participants) (4.43 \pm 2.84$)$ 
Table II. SARS-CoV-2 antibody titers according to demographics, anthropometric variables and smoking status.

\begin{tabular}{|c|c|c|c|c|}
\hline \multirow[b]{2}{*}{ Characteristic } & \multicolumn{3}{|c|}{ SARS-CoV-2 antibody titers } & \multirow[b]{2}{*}{ P-value } \\
\hline & Mean & SD & Median & \\
\hline $\operatorname{Sex}$ & & & & $0.007^{\mathrm{a}}$ \\
\hline Female & 4.44 & 2.70 & 3.97 & \\
\hline Male & 3.89 & 2.84 & 3.28 & \\
\hline Age groups, divided in years & & & & $<0.001^{\mathrm{b}}$ \\
\hline$\leq 30$ & 5.45 & 2.97 & 5.42 & \\
\hline $31-40$ & 4.43 & 2.91 & 3.68 & \\
\hline $41-50$ & 4.42 & 2.70 & 3.70 & \\
\hline $51-60$ & 3.94 & 2.65 & 3.37 & \\
\hline$\geq 61$ & 3.23 & 2.42 & 2.57 & \\
\hline BMI groups (k/m²) & & & & $0.063^{\mathrm{b}}$ \\
\hline$<20$ & 4.84 & 3.16 & 3.90 & \\
\hline$\geq 20$ and $<25$ & 4.41 & 2.56 & 4.06 & \\
\hline$\geq 25$ and $<28$ & 3.95 & 2.62 & 3.45 & \\
\hline$\geq 28$ and $<30$ & 3.53 & 2.69 & 2.89 & \\
\hline$\geq 30$ & 4.15 & 2.92 & 3.63 & \\
\hline Smoking status & & & & $0.003^{\mathrm{a}}$ \\
\hline No & 4.48 & 2.79 & 4.01 & \\
\hline Yes & 3.80 & 2.64 & 2.98 & \\
\hline
\end{tabular}

P-values were obtained using the ${ }^{\mathrm{a}}$ Mann-Whitney test or ${ }^{\mathrm{b}}$ Kruskal-Wallis test.

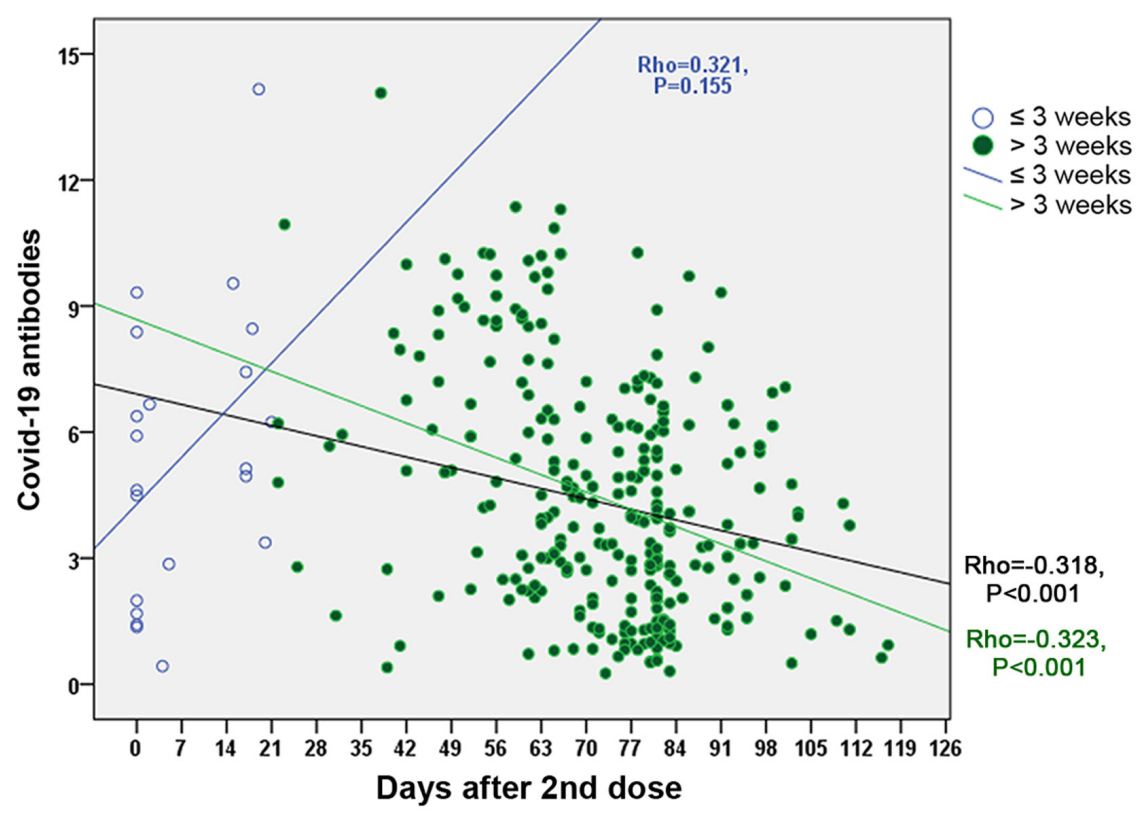

Figure 3. Scatterplot with correlation lines for the 319 cases of anti-SARS-CoV-2 IgG titers for whom both vaccination dates were known (black line). Data were additionally divided into two time groups: $\leq 3$ weeks (phase of 'developing' antibodies, blue line; and $>3$ weeks, green line).

labelled with green non-solid dots vs. the mean value of the whole group (all 517 participants) did not exhibit any statistically significant difference $(\mathrm{P}=0.339)$.

The time (days) of blood sampling post-vaccination ranged from 0 to 117 days with a mean period of $69.0 \pm 23.5$ days. statistically significant negative correlation was found between the antibody titers from all cases $(\mathrm{Rho}=-0.318, \mathrm{P}<0.001$; black line), while for the time post-vaccination in 319 cases exhibited a similar association ( $\mathrm{Rho}=-0.323, \mathrm{P}<0.001$; green line). However, no statistically significant correlation was found between the antibody titers in participants whose blood samples were obtained $<3$ weeks post-vaccination after the 
Table III. Antibody titers according to nutritional status, the use of immunosuppressants and corticosteroids (data retrieved from self-reported questionnaire).

SARS-CoV-2 antibody titers

\begin{tabular}{|c|c|c|c|c|c|c|c|}
\hline \multirow[b]{2}{*}{ Variables } & \multicolumn{3}{|c|}{ No } & \multicolumn{3}{|c|}{ Yes } & \multirow[b]{2}{*}{ P-value } \\
\hline & Mean & $\mathrm{SD}$ & Median & Mean & $\mathrm{SD}$ & Median & \\
\hline \multicolumn{8}{|l|}{ Deficiency } \\
\hline $\mathrm{Fe}$ & 4.20 & 2.76 & 3.64 & 4.66 & 2.87 & 4.00 & 0.180 \\
\hline Vitamin D & 4.35 & 2.86 & 3.79 & 4.06 & 2.57 & 3.52 & 0.489 \\
\hline Vitamin B12 & 4.29 & 2.84 & 3.60 & 4.16 & 2.44 & 3.90 & 0.947 \\
\hline Folic acid & 4.31 & 2.79 & 3.73 & 4.07 & 2.87 & 3.33 & 0.536 \\
\hline \multicolumn{8}{|l|}{ Use of } \\
\hline Immunosuppressants & 4.27 & 2.76 & 3.68 & 3.56 & 3.05 & 2.78 & 0.134 \\
\hline Corticosteroids & 4.29 & 2.78 & 3.68 & 3.21 & 2.30 & 2.44 & 0.064 \\
\hline
\end{tabular}

P-values were obtained using the Mann-Whitney test. Fe, iron.

final dose of the vaccine $(\mathrm{Rho}=0.321, \mathrm{P}=0.155)$ (blue line) (Fig. 3).

The SARS-CoV-2 antibody titers according to demographics, anthropometric variables and smoking status are presented in Table II. Females had higher antibody titers $(4.44 \pm 2.70)$ compared with males $(3.89 \pm 2.84 ; \mathrm{P}=0.007)$ Statistically significant differences were also observed between non-smokers (4.48 \pm 2.79$)$ and smokers (3.80 \pm 2.64 ; $\mathrm{P}=0.003)$. An older age was also associated with lower antibody titers $(\mathrm{P}<0.001)$. No statistically significant differences in antibody titers was observed among the different BMI groups. As regards the self-reported vitamin D, B12, folic acid and Fe deficiency, no significant differences were observed in the antibody titers. In addition, the titers of patients who used immunomodifiers did not markedly differ from that of the general population titer (all $\mathrm{P}>0.050$ ) (Table III).

The antibody titers according to the self-reported adverse effects post-vaccination are presented in Table IV. Participants reporting any adverse effects had higher titers compared with those reporting no effects $(\mathrm{P}=0.002)$. A similar observation was made for participants with systemic adverse effects compared with those having no systemic adverse effects $(\mathrm{P}=0.001)$. Higher antibody titers were found in participants who experienced redness at the injection site $(4.72 \pm 2.78, \mathrm{P}=0.047$, discomfort $(4.57 \pm 2.85 \mathrm{P}=0.015)$, headache $(4,87 \pm 2,86$, $\mathrm{P}=0.001)$, myalgia $4.81 \pm 2.99, \mathrm{P}=0.003)$ and sickness/malaise (4.58 $\pm 2.69 ; \mathrm{P}=0.007)$, chilling and fever compared with those who reported none of the aforementioned symptoms.

From the multivariate linear regression analysis (Table V), age and time (days) of sampling post-vaccination were negatively associated with antibody titers. Myalgia was positively associated with antibody titers.

\section{Discussion}

SARS-CoV-2 has become one of the most pronounced health challenges of the 21st century, affecting not only the global healthcare systems, but the socioeconomic systems as well. In order to halt its progression and protect those individuals who are at a high risk of developing severe COVID-19 infection, national authorities implemented a series of emergency measures among which were restrictions in transportation, socialization and periodic lockdowns $(21,22)$. Despite certain transient improvements in infection rates, these measures had major side-effects, such as the economic stagnation and social/psychological impairment that numerous individuals experienced (23). In order to address these issues, considerable investments in human and financial resources have been made in order to identify a solution that will allow a safe, rapid and permanent return to normality (24).

In the absence of specific pharmacotherapy (25-29), vaccines are expected to play an important role in suppressing the COVID-19 pandemic (30). Several vaccine platforms have been tested, such as those containing protein subunits, virus-like particles, DNA or RNA sequences, non-replicating viral vectors, replicating viral vectors, inactivated SARS-CoV-2 and live attenuated SARS-CoV-2 (31). To date, 297 vaccines are in development; 112 are currently undergoing clinical testing (https://www.who. $\mathrm{int} /$ publications $/ \mathrm{m} /$ item/draft-landscape-of-covid-19-candidatevaccines) (45 in phase 3 clinical trials https://covid19.trackvaccines.org/vaccines/) and 22 have received authorization by at least one country (https://covid19.trackvaccines.org/trials-vacc ines-by-country/\#trials); however, only four are widely authorized for emergency use (https://www.covid-19vaccinetracker. org/). One of the first vaccines that was authorized for emergency use was the BNT162b2 COVID-19 mRNA vaccine (32). It contains mRNA that encodes the $\mathrm{S}$ protein, a trimeric transmembrane glycoprotein located on the surface of the virus that plays a key role in viral entry into host cells. The mRNA is encapsulated in a lipid nanoparticle in order to protect it from degradation before entering the target cells. Following injection, the nanoparticles fuse with the target cell membrane and release the mRNA in the cytoplasm where it is translated 
Table IV. Antibody titers according to self-reported adverse effects post-vaccination.

\begin{tabular}{|c|c|c|c|c|c|}
\hline \multirow[b]{3}{*}{ Adverse effects } & \multicolumn{4}{|c|}{ SARS-CoV-2 antibody titers } & \multirow[b]{3}{*}{ P-value } \\
\hline & \multicolumn{2}{|c|}{ No } & \multicolumn{2}{|c|}{ Yes } & \\
\hline & Mean & SD & Mean & SD & \\
\hline Any symptom & 3.47 & 2.47 & 4.41 & 2.79 & 0.002 \\
\hline Regional & 3.94 & 2.77 & 4.37 & 2.76 & 0.087 \\
\hline Neuro/sensory & 4.17 & 2.78 & 4.54 & 2.73 & 0.146 \\
\hline Cardio/-respiratory & 4.28 & 2.77 & 3.97 & 2.79 & 0.492 \\
\hline Systemic & 3.79 & 2.61 & 4.57 & 2.82 & 0.001 \\
\hline $\begin{array}{l}\text { Allergic reactions (generalized rash, anaphylaxis, } \\
\text { facial or throat swelling) }\end{array}$ & 4.27 & 2.77 & 3.61 & 2.54 & 0.621 \\
\hline \multicolumn{6}{|l|}{ Regional (at injection site) } \\
\hline Pain & 3.93 & 2.76 & 4.37 & 2.78 & 0.074 \\
\hline Swelling & 4.11 & 2.68 & 4.76 & 3.05 & 0.104 \\
\hline Redness & 4.16 & 2.76 & 4.72 & 2.78 & 0.047 \\
\hline \multicolumn{6}{|l|}{ Neuro/sensory } \\
\hline Nausea & 4.14 & 2.72 & 5.19 & 2.99 & 0.053 \\
\hline Dizziness/weakness & 4.15 & 2.75 & 4.44 & 2.74 & 0.297 \\
\hline \multicolumn{6}{|l|}{ Cardio-respiratory } \\
\hline Tachycardia & 4.24 & 2.74 & 3.62 & 2.89 & 0.181 \\
\hline Heart palpitations & 4.25 & 2.77 & 4.60 & 2.79 & 0.526 \\
\hline \multicolumn{6}{|l|}{ Systemic reactions } \\
\hline Discomfort & 3.96 & 2.65 & 4.57 & 2.85 & 0.015 \\
\hline Headache & 3.98 & 2.67 & 4.87 & 2.86 & 0.001 \\
\hline Myalgia/muscle pain & 3.95 & 2.59 & 4.81 & 2.99 & 0.003 \\
\hline Gastrointestinal disorders & 4.17 & 2.73 & 4.93 & 3.07 & 0.214 \\
\hline Malaise & 4.00 & 2.76 & 4.58 & 2.69 & 0.007 \\
\hline Chills & 3.98 & 2.62 & 5.19 & 3.07 & 0.001 \\
\hline Fever & 4.08 & 2.71 & 5.21 & 2.86 & 0.004 \\
\hline Arthralgia & 4.14 & 2.72 & 4.60 & 2.88 & 0.186 \\
\hline Lymphadenopathy & 4.17 & 2.75 & 5.10 & 2.61 & 0.085 \\
\hline Insomnia & 4.18 & 2.74 & 4.92 & 2.94 & 0.316 \\
\hline
\end{tabular}

P-values were obtained using the Mann-Whitney test.

into S protein. Subsequently, the cell projects the protein on to its surface, which results in the development of an immune response and the production of antibodies (33).

In Greece, the vaccination program against SARS-CoV-2 was initiated on December 27, 2020 with the first vaccine available for use being the BNT162b2 COVID-19 mRNA vaccine. Since then, three more vaccines, namely Ad26.COV2.S (34), mRNA-1273 (35), ChAdOx1 nCoV-19 (36), became available, accelerating the progress of the vaccination program and achieving >5.5 million vaccinations as of July, 2021 (https://emvolio.gov.gr/; accessed August 20, 2021). However, a major issue of anti-SARS-CoV-2 vaccination that is not yet fully understood is the levels of anti-SARS-CoV-2 antibody titers following complete vaccination, and the various parameters that may affect this. The present study demonstrates that the IgG antibody titers induced by the BNT162b2 COVID-19
mRNA vaccine are significantly dependent on and correlated with both modifiable and non-modifiable parameters. Non-modifiable parameters include: i) Age, with younger adults developing higher IgG titers than older adults; and ii) sex, with females developing higher titers than males. Moreover, the presence of any systemic or non-systemic symptoms following inoculation was associated with higher antibody titers. On the other hand, among the modifiable parameters that were proven to affect antibody titers is the smoking habit, with non-smokers having higher IgG titers than smokers (37). In addition, the time of sampling after the second vaccine dose appeared to negatively correlate with antibody titers starting from the third week post-vaccination. This suggests that monitoring for a potential decrease in the immune response should be performed at 3 weeks post-vaccination. These findings are of utmost importance, since they suggest that those individuals 
Table V. Multivariate linear regression analysis of antibody titer sampling post-vaccination.

SARS-CoV-2 antibody titers

\begin{tabular}{lcccrr} 
& \multicolumn{3}{c}{ Unstandardised } & & Standardised \\
\cline { 2 - 3 } Variables & $\beta$ & $95 \%$ LL & $95 \%$ UL & & $\beta$ \\
\hline Age & -0.064 & -0.091 & -0.038 & -0.268 & $<0.001$ \\
Sex & -0.074 & -0.750 & 0.601 & -0.012 & 0.829 \\
Smoking status & -0.574 & -1.211 & 0.063 & -0.096 & 0.077 \\
Days after 2nd dose & -0.040 & -0.053 & -0.027 & -0.331 & $<0.001$ \\
Redness & 0.132 & -0.694 & 0.957 & 0.017 & 0.754 \\
Discomfort & -0.194 & -1.015 & 0.626 & -0.034 & 0.641 \\
Headache & -0.056 & -0.775 & 0.662 & -0.009 & 0.878 \\
Myalgia/muscle pain & 0.821 & 0.004 & 1.638 & 0.134 & 0.049 \\
Malaise & -0.038 & -0.852 & 0.775 & -0.006 & 0.926 \\
Chills & 0.010 & -0.907 & 0.927 & 0.001 & 0.983 \\
Fever & 0.606 & -0.496 & 1.708 & 0.068 & 0.280 \\
\hline
\end{tabular}

Standardised and unstandardized beta with $95 \%$ coefficients are presented, estimated after applying multivariate linear regression using SARS2-COVID-19 antibodies as dependent and demographics, smoking status, time of sample collection post-vaccination and adverse effects as explanatory variables. LL, lower limit; UL, upper limit of $95 \%$ coefficients.

who are at a greater risk of developing severe COVID-19 infection (older individuals, smokers) are in fact the same individuals who will not develop high titers of IgG antibodies. These individuals may thus be vulnerable for SARS-CoV-2 infection despite immunization or their immunization may last as long as that of other individuals. However, even though some studies have suggested that IgG titers in vaccinated individuals decline over time, the exact rate of this decline in $\operatorname{IgG}$ titers or the critical titer level up to which they can still be considered as adequately protected from infection and disease, remain unclear (38). At this point, it should be emphasized that the immune system may produce a series of antibody variants, each with a different neutralizing capacity, depending on the exact target-epitope (39-42).

Notably, a multicenter, perspective study (named CRO-VAX HCP) was conducted recently in Belgium on 200 subjects having received the BNT162b2 mRNA COVID-19 vaccine, aiming to assess the antibody response (41). To this end, antibodies against the SARS-CoV-2 nucleocapsid and SARS-CoV-2 S protein were measured in different time points, ranging from 14 to 90 days. Of note, a significant decrease in antibody titers was observed at 3 months compared with the peak response, with the antibody response being higher in seropositive compared with initially seronegative participants (41). A second study was also performed, enrolling a homogenous healthcare workers group in Romania, in an attempt to investigate the immunity status of subjects having received the BNT162b2 mRNA COVID-19 vaccine as well (42). In this framework, it was found that following the first vaccination dose, the IgG levels in non-infected subjects exhibited an increase of $\sim 12$-fold in males and one of $\sim 11$-fold in females; however, following the second round of vaccination, the $\mathrm{IgG}$ levels increased 1.33 -fold in males and 2.11-fold in females, when compared with those after the first dose (42). Importantly, in that study, the most prevalent adverse effects observed were pain at the injection site and flu-like symptoms, which are in accordance with the findings of the present study. Moreover, in another study that involved 203 patients who had recovered from SARS-CoV-2 infection in Denmark, broad serological profiles within the cohort were reported, with the majority of patients having robust adaptive immune responses regardless of their disease severity (43). Of note, the viral surface spike protein was identified as the dominant target for both neutralizing antibodies and $\mathrm{CD} 8^{+}$ T-cell responses.

In conclusion, crucial questions remain to be answered as regards the duration of immunity post-vaccination. The findings of the present study highlight the need for more effective and detailed immunosurveillance programs. Such programs are required to focus on those individuals that the present study identified and to closely monitor their IgG titers in order to identify in an early stage when they should receive a third dose of the vaccine.

\section{Acknowledgements}

The authors would like to thank the nursing and medical personnel of the Venizeleion General Hospital of Heraklion and the General Hospital of Ierapetra for their valuable work in blood sampling.

\section{Funding}

The present study was funded by Spin-Off Toxplus S.A. and supported by the Special Research Account of University of Crete (ELKE nos. 4602, 4920 and 3963). 


\section{Availability of data and materials}

The datasets used and/or analysed during the current study are available from the corresponding author on reasonable request.

\section{Authors' contributions}

AT conceived and designed the study. EV and MT conducted the experiments, interpreted the data and wrote the manuscript. MF performed the statistical analysis and interpreted the data. KP, TKN, GP, EH, NCP, ND, EI, GNG, MK, GL, SK and AA, drafted the manuscript, interpreted the data and critically revised the article. KF conceived and designed, and critically revised the study, and also provided the laboratory infrastructure and was responsible for the critical revision of the article for important intellectual content. DAS edited the manuscript, was involved in the conception and design of the study, and was responsible for the critical revision of the article for important intellectual content. AT and AA confirm the authenticity of all the raw data. All authors have read and approved the final manuscript.

\section{Ethics approval and consent to participate}

Blood and information of the study participants were obtained with written informed consent. Procedures involving participants in the present study were approved by the Human Ethics Committee at the University Hospital of Heraklion on July, 2021 and by the Scientific Council of Venizeleion General Hospital of Heraklion on March, 2021 as well as by the Scientific Council of Ierapetra on April, 2021.

\section{Patient consent for publication}

Not applicable.

\section{Competing interests}

DAS is the Editor-in-Chief for the journal, but had no personal involvement in the reviewing process, or any influence in terms of adjudicating on the final decision, for this article. The other authors declare that they have no competing interests.

\section{References}

1. Docea AO, Tsatsakis A, Albulescu D, Cristea O, Zlatian O, Vinceti M, Moschos SA, Tsoukalas D, Goumenou M, Drakoulis N, et al: A new threat from an old enemy: Re-emergence of coronavirus (Review). Int J Mol Med 45: 1631-1643, 2020.

2. Neagu M, Calina D, Docea AO, Constantin C, Filippini T, Vinceti M, Drakoulis N, Poulas K, Nikolouzakis TK, Spandidos DA, et al: Back to basics in COVID-19: Antigens and antibodies-Completing the puzzle. J Cell Mol Med 25: 4523-4533, 2021.

3. Latinne A, Hu B, Olival KJ, Zhu G, Zhang L, Li H, Chmura AA, Field HE, Zambrana-Torrelio C, Epstein $\mathrm{JH}$, et al: Origin and cross-species transmission of bat coronaviruses in China. Nat Commun 11: 4235, 2020.

4. Mittal A, Manjunath K, Ranjan RK, Kaushik S, Kumar S and Verma V: COVID-19 pandemic: Insights into structure, function, and hACE2 receptor recognition by SARS-CoV-2. PLoS Pathog 16: e1008762, 2020.

5. Walls AC, Park YJ, Tortorici MA, Wall A, McGuire AT and Veesler D: Structure, Function, and Antigenicity of the SARS-CoV-2 Spike Glycoprotein. Cell 181: 281-292.e6, 2020.
6. Hoffmann M, Kleine-Weber H, Schroeder S, Krüger N, Herrler T, Erichsen S, Schiergens TS, Herrler G, Wu NH, Nitsche A, et al: SARS-CoV-2 Cell Entry Depends on ACE2 and TMPRSS2 and Is Blocked by a Clinically Proven Protease Inhibitor. Cell 181: 271-280.e8, 2020.

7. Min L and Sun Q: Antibodies and Vaccines Target RBD of SARS-CoV-2. Front Mol Biosci 8: 671633, 2021.

8. Calina D, Hartung T, Mardare I, Mitroi M, Poulas K, Tsatsakis A, Rogoveanu I and Docea AO: COVID-19 pandemic and alcohol consumption: Impacts and interconnections. Toxicol Rep 8: 529-535, 2021.

9. Pennisi M, Lanza G, Falzone L, Fisicaro F, Ferri R and Bella R: Sars-cov-2 and the nervous system: From clinical features to molecular mechanisms. Int J Mol Sci 21: 1-21, 2020.

10. Silva FAFD, Brito BB, Santos MLC, Marques HS, Silva Júnior RTD, Carvalho LS, Vieira ES, Oliveira MV and Melo FF: COVID-19 gastrointestinal manifestations: A systematic review. Rev Soc Bras Med Trop 53: e20200714, 2020.

11. Falzone L, Gattuso G, Tsatsakis A, Spandidos DA and Libra M: Current and innovative methods for the diagnosis of COVID-19 infection (Review). Int J Mol Med 47: 47, 2021.

12. Thakkar S, Arora S, Kumar A, Jaswaney R, Faisaluddin M, Ammad Ud Din M, Shariff M, Barssoum K, Patel HP, Nirav A, et al: A Systematic Review of the Cardiovascular Manifestations and Outcomes in the Setting of Coronavirus-19 Disease. Clin Med Insights Cardiol 14: 1179546820977196, 2020.

13. Tsatsakis A, Calina D, Falzone L, Petrakis D, Mitrut R, Siokas V, Pennisi M, Lanza G, Libra M, Doukas SG, et al: SARS-CoV-2 pathophysiology and its clinical implications: An integrative overview of the pharmacotherapeutic management of COVID-19. Food Chem Toxicol 146: 111769, 2020.

14. Sidiropoulou P, Docea AO, Nikolaou V, Katsarou MS, Spandidos DA, Tsatsakis A, Calina D and Drakoulis N: Unraveling the roles of vitamin D status and melanin during COVID-19 (Review). Int J Mol Med 47: 92-100, 2021.

15. Skalny AV, Rink L, Ajsuvakova OP, Aschner M, Gritsenko VA, Alekseenko SI, Svistunov AA, Petrakis D, Spandidos DA, Aaseth J, et al: Zinc and respiratory tract infections: Perspectives for COVID-19 (Review). Int J Mol Med 46: 17-26, 2020.

16. Kostoff RN, Kanduc D, Porter AL, Shoenfeld Y, Calina D, Briggs MB, Spandidos DA and Tsatsakis A: Vaccine- and natural infection-induced mechanisms that could modulate vaccine safety. Toxicol Rep 7: 1448-1458, 2020.

17. Moura DTH, McCarty TR, Ribeiro IB, Funari MP, Oliveira PVAG, Miranda Neto AA, Monte Júnior ESD, Tustumi F, Bernardo WM, Moura EGH, et al: Diagnostic characteristics of serological-based COVID-19 testing: A systematic review and meta-analysis. Clinics (São Paulo) 75: e2212, 2020.

18. Kubina R and Dziedzic A: Molecular and serological tests for COVID-19. A comparative review of SARS-CoV-2 coronavirus laboratory and point-of-care diagnostics. Diagnostics (Basel) 10: 434, 2020.

19. Childs CE, Calder PC and Miles EA: Diet and immune function. Nutrients 11: 1933, 2019.

20. Mikkelsen K and Apostolopoulos V: Vitamin B12, Folic Acid, and the Immune System. In: Nutrition and Immunity. Springer International Publishing, New York, NY, pp103-114, 2019.

21. The Lancet Respiratory Medicine: COVID-19 transmission - up in the air. Lancet Respir Med 8: 1159, 2020.

22. Farsalinos K, Poulas K, Kouretas D, Vantarakis A, Leotsinidis M, Kouvelas D, Docea AO, Kostoff R, Gerotziafas GT, Antoniou MN, et al: Improved strategies to counter the COVID-19 pandemic: Lockdowns vs. primary and community healthcare. Toxicol Rep 8: 1-9, 2021.

23. Tsatsakis A, Petrakis D, Nikolouzakis TK, Docea AO, Calina D, Vinceti M, Goumenou M, Kostoff RN, Mamoulakis C, Aschner M, et al: COVID-19, an opportunity to reevaluate the correlation between long-term effects of anthropogenic pollutants on viral epidemic/pandemic events and prevalence. Food Chem Toxicol 141: 111418, 2020

24. Goumenou M, Sarigiannis D, Tsatsakis A, Anesti O, Docea AO, Petrakis D, Tsoukalas D, Kostoff R, Rakitskii V, Spandidos DA, et al: COVID-19 in Northern Italy: An integrative overview of factors possibly influencing the sharp increase of the outbreak (Review). Mol Med Rep 22: 20-32, 2020.

25. Pott-Junior H, Paoliello MMB, Miguel AQC, da Cunha AF, de Melo Freire CC, Neves FF, da Silva de Avó LR, Roscani MG, Dos Santos SS and Chachá SGF: Use of ivermectin in the treatment of Covid-19: A pilot trial. Toxicol Rep 8: 505-510, 2021. 
26. Vivarelli S, Falzone L, Torino F, Scandurra G, Russo G, Bordonaro R, Pappalardo F, Spandidos DA, Raciti G and Libra M: Immune-checkpoint inhibitors from cancer to COVID-19: A promising avenue for the treatment of patients with COVID-19 (Review). Int J Oncol 58: 145-157, 2021.

27. Lam S, Lombardi A and Ouanounou A: COVID-19: A review of the proposed pharmacological treatments. Eur J Pharmacol 886: $173451,2020$.

28. Hashem AM, Alghamdi BS, Algaissi AA, Alshehri FS, Bukhari A, Alfaleh MA and Memish ZA: Therapeutic use of chloroquine and hydroxychloroquine in COVID-19 and other viral infections: A narrative review. Travel Med Infect Dis 35: 101735, 2020.

29. Vivarelli S, Falzone L, Grillo CM, Scandurra G, Torino F and Libra M: Cancer Management during COVID-19 Pandemic: Is Immune Checkpoint Inhibitors-Based Immunotherapy Harmful or Beneficial? Cancers (Basel) 12: 1-22, 2020.

30. Calina D, Docea AO, Petrakis D, Egorov AM, Ishmukhametov AA, Gabibov AG, Shtilman MI, Kostoff R, Carvalho F, Vinceti M, et al: Towards effective COVID-19 vaccines: Updates, perspectives and challenges (Review). Int J Mol Med 46: 3-16, 2020.

31. Calina D, Sarkar C, Arsene AL, Salehi B, Docea AO, Mondal M, Islam MT, Zali A and Sharifi-Rad J: Recent advances, approaches and challenges in targeting pathways for potential COVID-19 vaccines development. Immunol Res 68: 315-324, 2020.

32. Polack FP, Thomas SJ, Kitchin N, Absalon J, Gurtman A, Lockhart S, Perez JL, Pérez Marc G, Moreira ED, Zerbini C, et al C4591001 Clinical Trial Group: Safety and Efficacy of the BNT162b2 mRNA Covid-19 Vaccine. N Engl J Med 383 2603-2615, 2020.

33. Centers for Disease Control and Prevention (CDC): Understanding mRNA COVID-19 Vaccines. CDC, Atlanta, GA, 2021. https://www.cdc.gov/coronavirus/2019-ncov/vaccines/ different-vaccines/mrna.html. Updated March 4, 2021.

34. Sadoff J, Gray G, Vandebosch A, Cárdenas V, Shukarev G, Grinsztejn B, Goepfert PA, Truyers C, Fennema H, Spiessens B, et al; ENSEMBLE Study Group: Safety and Efficacy of Single-Dose Ad26.COV2.S Vaccine against Covid-19. N Engl J Med 384: 2187-2201, 2021.

35. Baden LR, El Sahly HM, Essink B, Kotloff K, Frey S, Novak R, Diemert D, Spector SA, Rouphael N, Creech CB, et al; COVE Study Group: Efficacy and Safety of the mRNA-1273 SARS-CoV-2 Vaccine. N Engl J Med 384: 403-416, 2021.
36. Voysey M, Clemens SAC, Madhi SA, Weckx LY, Folegatti PM, Aley PK, Angus B, Baillie VL, Barnabas SL, Bhorat QE, et al; Oxford COVID Vaccine Trial Group: Safety and efficacy of the ChAdOx1 nCoV-19 vaccine (AZD1222) against SARS-CoV-2: An interim analysis of four randomised controlled trials in Brazil, South Africa, and the UK. Lancet 397: 99-111, 2021.

37. Alexandris N, Lagoumintzis G, Chasapis CT, Leonidas DD, Papadopoulos GE, Tzartos SJ, Tsatsakis A, Eliopoulos E, Poulas K and Farsalinos K: Nicotinic cholinergic system and COVID-19: In silico evaluation of nicotinic acetylcholine receptor agonists as potential therapeutic interventions. Toxicol Rep 8: 73-83, 2020.

38. Hernández AF, Calina D, Poulas K, Docea AO and Tsatsakis AM: Safety of COVID-19 vaccines administered in the EU: Should we be concerned? Toxicol Rep 8: 871-879, 2021.

39. Gerbase-DeLima M, de Marco R, Monteiro F, Tedesco-Silva H, Medina-Pestana JO and Mine KL: Impact of Combinations of Donor and Recipient Ages and Other Factors on Kidney Graft Outcomes. Front Immunol 11: 954, 2020.

40. Petrakis D, Margină D, Tsarouhas K, Tekos F, Stan M, Nikitovic D, Kouretas D, Spandidos DA and Tsatsakis A: Obesity - a risk factor for increased COVID-19 prevalence, severity and lethality (Review). Mol Med Rep 22: 9-19, 2020.

41. Favresse J, Bayart J-L, Mullier F, Elsen M, Eucher C, Van Eeckhoudt S, Roy T, Wieers G, Laurent C, Dogné JM, et al: Antibody titres decline 3-month post-vaccination with BNT162b2. Emerg Microbes Infect 10: 1495-1498, 2021.

42. Zurac S, Nichita L, Mateescu B, Mogodici C, Bastian A, Popp C, Cioplea M, Socoliu C, Constantin C and Neagu M: COVID-19 vaccination and $\operatorname{IgG}$ and $\operatorname{Ig} \mathrm{A}$ antibody dynamics in healthcare workers. Mol Med Rep 24: 578, 2021

43. Nielsen SS, Vibholm LK, Monrad I, Olesen R, Frattari GS, Pahus MH, Højen JF, Gunst JD, Erikstrup C, Holleufer A, et al: SARS-CoV-2 elicits robust adaptive immune responses regardless of disease severity. EBioMedicine 68: 103410, 2021.

This work is licensed under a Creative Commons Attribution-NonCommercial-NoDerivatives 4.0 International (CC BY-NC-ND 4.0) License. 